\title{
Financiamento, produção e identidade cultural-corporativa: as empre- sas culturalmente responsáveis
}

\author{
Financiación de la producción y la identidad cultural, empresarial, \\ empresas culturalmente responsable
}

\author{
Financing, production and cultural identity, corporate, firms culturally \\ responsible
}

\author{
Elder Patrick Maia*
}

Palavras chave:

Gestão

Empresas

Cultura

Usos e valor simbólico
Resumo:

O crescimento do interesse das corporações empresariais junto aos projetos, ações e programas culturais deriva da valorização da dimensão propriamente simbólico-cultural no cotidiano das práticas de consumo. Com efeito, com vistas a aproximar a marca dos consumidores e dos demais agentes que compõem a mesma, as grandes corporações cada vez mais investem em ações de cunho cultural. Para tanto, lançam mão dos principais dispositivos legais de financiamento, assim como utilizam recursos próprios para engendrar projetos culturais corporativos, como o Programa Petrobras Cultural e o Programa BNB de Cultura. Esses investimentos instauram novas formas de usos da cultura e impõem novos mecanismos de gestão, que corroboram para a complexificação da gestão institucional da marca. Através desses novos mecanismos, o valor simbólico e econômico de uma marca se aproximam, se cruzam e assumem posições desconhecidas há cerca de duas décadas atrás.

\footnotetext{
* Professor Adjunto I do Instituto de Ciências Sociais (ICS) da Universidade Federal de Alagoas (UFAL), setor de sociologia, e professor do Programa de Pós-Graduação em Sociologia (PPGS-UFAL) da mesma instituição. É membro do grupo de pesquisa Cultura, memória e desenvolvimento (UnB, UESB, UFRB, PUC e UFAL), pertence a linha de pesquisa Cultura, patrimônio e memória do PPGS, e também membro do Laboratório de Investigação sociológica (SocioLab), além de vice-coordenador do PPGS-UFAL.Tem experiência na área de Sociologia, com ênfase em teoria sociológica e Sociologia da cultura, atuando principalmente nos seguintes temas: cultura popular, sertão nordestino, consumo simbólico, sociologia dos intelectuais, pensamento social brasileiro, economia da cultura e políticas culturais . É membro também do comitê editorial da Revista Latitude (PPGS-UFAL).
} 


\section{Resumen:}

El creciente interés de las empresas de los proyectos, iniciativas y programas culturales se deriva de la apreciación correcta de la dimensión simbólica cultural en las prácticas de consumo cotidiano. En efecto, con el fin de llevar la marca entre los consumidores y otros agentes que la componen, las grandes empresas han invertido en acciones cada vez más de un rasgo cultural. A tal efecto, el recurso a las principales disposiciones legislativas para la financiación y utilizar sus propios recursos para generar proyectos de empresas culturales, tales como el Programa Petrobras Cultural y el Programa de Cultura BNB. Estas inversiones se introducen nuevas formas de utilizar la cultura e imponer nuevos mecanismos de gestión, que corroboran la complejidad de la gestión de marca corporativa. A través de estos nuevos mecanismos, el valor simbólico y económico de un enfoque de marca, cruce y asumir posiciones desconocidas para hace casi dos décadas.

\section{Palabras clave:}

Gestión

La cultura corporativa

El valor de la costumbre y simbólica

\section{Key words:}

Management

Corporate culture

Custom and symbolic value

\section{Abstract:}

The growing interest of corporations from the projects, initiatives and cultural programs derives from the proper appreciation of the symbolic cultural dimension in everyday consumption practices. Indeed, in order to bring the brand among consumers and other agents that compose it, large corporations have increasingly invested in shares of a cultural trait. To that end, resort to the main legislative provisions for funding and use their own resources to engender corporate cultural projects, such as the Petrobras Cultural Program and the Program for Culture BNB. These investments will introduce new ways to use culture and impose new management mechanisms, which corroborate the complexity of managing corporate brand. Through these new mechanisms, the symbolic and economic value of a brand approach, cross over and assume positions unknown for nearly two decades ago. 


\section{Financiamento, produção e identidade cultural-corporativa: as empresas culturalmente responsáveis.}

\section{INTRODUÇÃO}

O esforço analítico e descritivo que se segue é resultado de uma investigação mais larga, que culminou com a publicação do trabalho $A$ economia simbólica da cultura popular sertanejo-nordestina ${ }^{1}$ e que aparece no bojo do processo contemporâneo ${ }^{2}$ de reforma da Lei Rouanet. Esse trabalho procura - mais do que revolver um terreno já assaz vasculhado (os impactos e desdobramentos da Lei Rouanet) - conduzir uma reflexão que permita compreender a trama de interesses empresarias existentes quando da utilização dos mecanismos legais de financiamento. Com efeito, intenciona-se indagar: por que e como determinadas empresas se interessam cada vez mais em participar da captação de recursos para realização de projetos culturais? E mais, quais os impactos da criação de novos mecanismos de gestão pública dos dispositivos fiscais de financiamento? Essas indagações, aliadas a outras que grassam no texto, permitem entender parte do sistema de usos que envolve, de maneira estrutural, a relação entre o desempenho econômico-financeiro de uma empresa e seu prestígio político-cultural. Em outros termos, o processo que envolve a gestão empresarial de uma marca (que necessariamente reclama ações educacionais, ambientais, culturais, entre outras) e, portanto, envolve a gestão de um determinado significado, e a dimensão propriamente econômico-material do empreendimento (comercialização, produção, preço, distribuição, fornecedores, tributação, oferta, demanda, consumo, concorrência, entre outros).
Com efeito, o texto busca apreender os usos implicados no processo de consolidação da cultura (produção e incentivo para realização de serviços e bens simbólico-culturais) como um recurso empresarial capaz de agregar valor simbólico-material à marca de determinadas companhias e empresas públicas e privadas. Para tanto, o texto divide-se em duas seções complementares, além das considerações finais, quais sejam: a primeira seção, intitulada financiamento, gestão da marca empresarial e prestígio simbólico-cultural, tem como desiderato apresentar o processo de captação e operacionalização dos recursos, cotejando e atualizados os dados acerca das principais leis federais de incentivo, para assim rastrear o processo pelo qual a cultura se sedimenta como recurso simbólico-material para as empresas, destacando alguns dispositivos de gestão do prestígio simbólico-cultural empresarial; a segunda seção, por sua vez, consiste em evidenciar e vicejar uma reflexão sobre os desdobramentos de dois programas culturais específicos, inscritos no âmbito das políticas culturais da Companhia de Petróleo Brasileiro S.A (Petrobras), através do Programa Petrobras Cultural, e do Banco do Nordeste do Brasil (BNB), mediante o Programa BNB de Cultura.

\section{FINANCIAMENTO, GESTÃO DA MARCA EMPRESARIAL E PRESTIIGIO SIMBÓLICO-CULTURAL}

As empresas e organizações, tanto as de capital misto (controladas pelo Estado), quanto as de capital privado, vêm assumindo um destaque considerável no panorama da economia criativa e das indústrias da criatividade. Em um trabalho de fôlego acerca do movimento contemporâneo de crescente interesse das organizações privadas pelas 
atividades artísticas e culturais, Chin-Tao $\mathrm{Wo}^{3}$ apresentou os resultados de uma pesquisa acerca da experiência do financiamento cultural nos anos oitenta $e$ noventa em países como os Estados Unidos e a Inglaterra. A autora sustenta que, a partir dos anos oitenta, quando da assunção ao poder de Ronald Reagan, no EUA, e de Margaret Thatcher, na Inglaterra, os recursos públicos destinados à cultura nesses países passaram a ser cada vez mais reduzidos. Essa redução pode ser comprovada através dos recursos públicos destinados ao NEA (National Endowment for the Art), nos Estados Unidos. Quando da sua criação, em 1965, o NEA possuía um orçamento de 2,8 milhões de dólares, quinze anos mais tarde, em 1980, esse orçamento já era de 154,6 milhões de dólares. A partir de então, o orçamento da agência foi progressivamente reduzido, chegando ao ano 2000 com apenas $50 \%$ dos recursos alcançados em 1980.

Por outro lado, grandes corporações privadas, como a Philip Morris, IBM, Unilever e British Telecom, passaram a destinar um volume crescente de recursos para as atividades artísticas e cultuais. Esse processo ocorreu, segundo Chin-Tao Wo (2006), primeiro porque os governos Reagan e Thatcher passaram a negligenciar e esvaziar os fundos públicos de cultura, manifestando um claro desinteresse pelas questões culturais, segundo porque a importância assumida pelas atividades e bens culturais na formação das identidades individuais e coletivas contemporâneas fez com que as corporações, como uma estratégia marketing, direcionassem parte de seus recursos para as atividades artísticas. Todavia, como adverte a autora, o investimento corporativo em atividades culturais, sobretudo nos Estados Unidos, já era parte constitutiva do financiamento da produção cultural desde o início do século XX. Desde esse período as grandes empresas, principalmente os bancos, mantinham coleções de obras raras, como quadros e esculturas que, invariavelmente, eram cedidas a museus públicos.

A grande novidade surgida a partir dos anos oitenta foi que as grandes corporações norte-americanas e britânicas passaram a criar suas próprias fundações de cultura, com seus museus, galerias e centros culturais, promovendo campanhas mundiais massivas, como a 50 Years of Collecting: Art at IBM, a Unilever House London Contemporary Art Collection: The First Twelve Years ou The Whitney Museum of American Art at Philip Morris. A associação de campanhas, museus, galerias, centros de cultura e arte aos nomes das empresas, às suas marcas e produtos tornou-se uma regularidade em todo o mundo. Por isso, a autora sustenta que houve (e utiliza o caso britânico e norte-americano para validar sua hipótese) uma privatização da cultura a partir dos anos oitenta. $\mathrm{Na}$ mesma direção, ressalta ainda que nesse período surgiram os "espaços públicos corporativos", locais abertos à visitação, à fruição e à contemplação estética, mas controlados e explorados publicitariamente pelas grandes corporações, que passaram a preencher esses espaços com suas coleções, exposições e espetáculos.

Seguindo uma direção assumida a partir dos anos setenta, a autora demonstra como a maioria das empresas investidoras pertence aos setores de serviços, notadamente os serviços financeiros. Agências financeiras, bancos, fundos de pensão e conglomerados financeiros são os que mais destinam recursos e associam suas marcas às linguagens artísticas (sobretudo no circuito das artes plásticas, dos festivais de música e das exposições de esculturas). Era muito comum até os 
anos sessenta a existência de grandes patrimônios familiares, quando algumas famílias controlavam a vida financeira (através da maioria das ações negociadas) de muitas corporações, como fábricas de alimentos, de cigarros, bancos, ente outras. Durante os anos oitenta cada vez mais o controle acionário das grandes corporações norte-americanas e britânicas, mas também em outros países como Alemanha e Japão, passaram para o controle de investidores institucionais, isto é, grandes investidores corporativos que administram um grande volume de recursos financeiros como, por exemplo, os fundos de pensão e companhias de seguros, que são administrados por bancos e instituições financeiras em geral. Segundo a autora, em 1979 cerca de $70 \%$ das ações negociadas na bolsa de Nova York já pertenciam a investidores institucionais ${ }^{4}$.

Com efeito, nos anos noventa essas organizações financeiras, como o banco holandês ABN-AMRO BANK (controlador do antigo Banco Real no Brasil, hoje Santander), o Banco de Boston, que também atua na América Latina, o Banco Itaú e Bradesco, no Brasil, além dos bancos de capital misto, como o Banco do Brasil e a Caixa Economia Federal, passaram a destinar recursos para a montagem de suas políticas culturais próprias, algumas estritamente inspiradas em uma hierarquia valorativa na qual os conceitos de criatividade, identidade e diversidade aparecem no cume, secundados pela teia discursiva que envolve as novas relações contemporâneas entre as categorias cultura e desenvolvimento (ALVES, 2011).

As reflexões e os materiais trazidos por Chin-Tao Wo são bastante sugestivos e elucidativos. No entanto, a experiência britânica e norte-americana é assaz distinta da experiência brasileira e de outros países, como a França, onde é possível se afirmar que, desde os anos cinquenta, vem ocorrendo o oposto da tendência assumida nos Estados Unidos e na Grã-Bretanha. No Brasil, a consolidação das leis de incentivo à cultura no decurso da década de noventa criou um desenho ambivalente de privatização e, ao mesmo tempo, estatização da cultura. Essa ambivalência precisa ser explorada com maior acuidade a partir da própria trama de operacionalização das leis de incentivo fiscal, cujo instituto da renúncia fiscal atua como o centro da ambivalência.

A primeira lei de incentivo à produção cultural no Brasil foi a chamada Lei Sarney, Lei Federal $n^{\circ} 7.505$, de 1986. A idéia de se conceder incentivos fiscais na prestação de contas do imposto de renda de pessoas físicas e jurídicas que realizassem atividades artísticas e culturais vinha sendo estudada desde os anos setenta (em 1972 foi apresentado ao congresso o embrião da Lei Sarney), mas só nos anos oitenta a lei foi aprovada e entrou em vigor. Estima-se ${ }^{5}$ que foram gastos cerca de U\$ 450 milhões em atividades artísticas e culturais nos quatro anos de vigência da lei (1986-1990), dos quais 112 milhões foram de incentivos fiscais e o restante decorrente da contrapartida dos patrocinadores. A lei, semelhante às demais que a sucederam, previa as três modalidades de incentivo: doação, patrocínio e investimento. Os projetos culturais eram apresentados diretamente às empresas por produtores culturais (artistas e profissionais da cultura em geral), que, por sua vez, realizavam os projetos (filmes, documentários, peças teatrais, shows populares, etc.) e solicitavam, mediante a prestação de contas do imposto de renda anual devido, o abatimento. Os projetos não passavam por uma seleção prévia no Ministério da Cultura, o que resultou em um conjunto 
de suspeitas de irregularidade na prestação de contas e, portanto, nos valores solicitados para desconto junto ao imposto devido. A Lei exigia apenas que o produtor cultural, captador do recurso, estivesse cadastrado em uma lista de profissionais e agentes culturais existentes no Ministério da Cultura.

Em 1991, em substituição à Lei Sarney, foi sancionada a lei $n^{0} 8313$, mais conhecida como Lei Rouanet, que só passou a vigorar a parir de sua regulamentação, com a publicação do Decreto $n^{\circ} 1.494$, em 17 de maio de 1995. A lei passou a exigir a avaliação e aprovação prévia dos projetos culturais, assim como criou o Fundo Nacional de Cultura (FNC), os Fundos de Investimento Cultural e Artístico (FICART) e o incentivo a projetos culturais (Mecenato). Em meio à revogação da Lei Sarney e promulgação da Lei Rouanet, algumas leis estaduais e municipais de incentivo à cultura foram criadas, como a Lei Mendonça (Lei n 10.923/90), do município de São Paulo, regulamentada em 1991. A Lei Mendonça facultava a dedução sobre o Imposto Sobre a Propriedade Predial e Territorial Urbana (IPTU) devido pelas pessoas físicas e jurídicas. A lei inspirou que diversos municípios adotassem mecanismos semelhantes de isenção fiscal baseado na cobrança do IPTU. Diante de um conjunto de críticas em torno das dificuldades de se obter recursos, decorrentes de seu excesso de rigor, a Lei Rouanet passou por uma reforma em 1995. As principais medidas foram no sentido de conceder maior celeridade ao processo de captação de recursos e oferecer novos meios de incentivo às empresas, como o aumento de $2 \%$ para $5 \%$ do desconto total em cima do imposto devido, além de campanhas de esclarecimento acerca do funcionamento e operacionalização da lei. A reforma da lei Rouanet foi antecedida pela promulgação da Lei $\mathrm{n}^{\circ}$ 8.685, também conhecida como lei do Audiovisual. A lei estabelece que os projetos previamente aprovados pelo Ministério da Cultura (MinC) tenham até 100\% dos recursos envolvidos descontados, mediante o limite máximo de $3 \%$ do total de imposto de renda devido para pessoas jurídicas e $5 \%$ para pessoas físicas.

A partir do início da gestão do ex-ministro da cultura Francisco Weffort esses dois instrumentos legais passaram a delinear o desenho da política cultural pública no Brasil. Se durante o governo Itamar Franco (1992-1994) apenas 72 empresas utilizaram os instrumentos da lei Rouanet para investir em cultura, somente no primeiro ano do governo Fernando Henrique Cardoso (1995-2002) esse número chegou a 235 , alcançando, em 1998, 1061 empresas $^{6}$. Esse substancial aumento se deu em função das alterações sofridas na lei, mas, sobretudo, em conseqüência das determinações governamentais para que as empresas estatais lançassem mão das prerrogativas da lei e destinassem recursos para projetos culturais. Com efeito, grandes projetos, em sua maioria concentrados na região Sudeste, foram realizados e um número cada vez maior de projetos passou a ser analisado pelo Ministério da Cultura, através da Secretaria de Incentivo e Fomento à Cultura. Imediatamente após o processo de privatização das empresas estatais de telefonia e infraestrutura, ocorrido no final dos anos noventa, o número de projetos apresentados e viabilizados foi reduzido, voltando a crescer após o ano 2000.

Nesse ano foram captados $\mathrm{R} \$$ 353 milhões tributários dos incentivos fiscais facultados pelas duas principais leis de incentivo em âmbito federal. A reformulação da Lei Rouanet, e sua sistemática utilização a partir de 1995, 
integraram, sob um único instituto jurídico, muitos mecanismos que antes estavam dispersos. As principais modalidades de financiamento presentes na lei são o Mecenato e o Fundo Nacional de Cultura (FNC). O Mecenato é composto pela doação, patrocínio e investimento. A rubrica mais utilizada é o patrocínio, que permite a empresa solicitar até $100 \%$ de desconto do recurso destinado para o projeto em questão. Os projetos culturais são apresentados à Secretaria de Fomento à Cultura, do Ministério da Cultura, através de um produtor cultural (previamente cadastrado), denominado proponente, que precisa cumprir as justificativas formais de apresentação dos projetos e aguardar a tramitação dos projetos no ministério: apresentação, aprovação e incentivo. A apresentação diz respeito à primeira etapa, na qual o proponente apresenta toda a documentação necessária à sua candidatura ao incentivo. Nessa etapa é necessário um grande controle orçamentário do projeto, das justificativas culturais e todas as demais informações sobre o proponente (que pode ser um produtor cultural isolado ou o departamento e/ou setor de cultura de uma determinada empresa).
Caso o projeto seja aprovado (ou seja, esteja habilitado ao incentivo), o Ministério da Cultura exigirá novos documentos e o projeto então se submeterá à última etapa, a do incentivo. Caso o proponente seja um produtor cultural isolado (muito comum no Brasil), ao final da última etapa o proponente recebe autorização do ministério para apresentar o projeto (já selecionado) a algum incentivador (pessoas jurídicas e físicas) disposto a realizar o projeto. A tabela 01 apresenta um esquadrinhamento dos percentuais em torno das três etapas de captação da Lei Rouanet.

A outra modalidade de incentivo presente no âmbito federal é o Fundo Nacional de Cultura (FNC). Grande parte dos recursos do fundo advém de receitas obtidas junto ao sistema de loterias federais, Fundos de Desenvolvimento Regional (FINOR, FINAM e FUNRES) e Tesouro Nacional. A sistemática de obtenção dos recursos junto ao fundo é bastante semelhante a do mecenato (doação, patrocínio e investimento), sendo que o fundo financia até o limite de $80 \%$ dos gastos e recursos necessários para a realização do projeto cultural aprovado,

Tabela 01 - Evolução do número de projetos apresentados, aprovados e incentivados, Lei Rouanet

\begin{tabular}{|c|c|c|c|}
\hline Ano & $\begin{array}{c}\text { Porcentual de projetos } \\
\text { apresentados que } \\
\text { foram aprovados }\end{array}$ & $\begin{array}{c}\text { Porcentual de projetos } \\
\text { aprovados que } \\
\text { foram incentivados }\end{array}$ & $\begin{array}{c}\text { Porcentual de projetos } \\
\text { apresentados que } \\
\text { foram incentivados }\end{array}$ \\
\hline 1998 & $55,0 \%$ & $24,9 \%$ & $13,9 \%$ \\
\hline 1999 & $40,4 \%$ & $28,6 \%$ & $11,5 \%$ \\
\hline 2000 & $49,6 \%$ & $34,2 \%$ & $17,0 \%$ \\
\hline 2001 & $33,8 \%$ & $42,6 \%$ & $14,4 \%$ \\
\hline 2002 & $47,4 \%$ & $32,0 \%$ & $15,2 \%$ \\
\hline 2003 & $56,1 \%$ & $37,9 \%$ & $21,2 \%$ \\
\hline 2004 & $78,1 \%$ & $33,4 \%$ & $26,1 \%$ \\
\hline
\end{tabular}

Fonte: Ministério da Cultura 
ficando os outros $20 \%$ como uma contrapartida da empresa, ao passo que o mecenato financia $100 \%$ do projeto. Esse percentual corroborou para que o mecenato, através das leis $n^{\circ} 8.113$ (Lei Rouanet) e Lei $n^{\circ} 9.874$ (Lei do Audiovisual), se tornasse a modalidade de incentivo predominante desde os anos noventa.

Existem duas modalidades mais recorrentes e que são contempladas pelas duas leis mais utilizadas no âmbito da produção cultural, a doação e o patrocínio. A doação se refere à transferência de recursos aos produtores e/ou aos produtos culturais, sem que exista e a obrigatoriedade de divulgação e promoção do nome do doador, portanto sem maiores compromissos publicitários. A doação também pode ser descontada no imposto de renda de pessoas e empresas. É uma modalidade de incentivo muito presente nos Estados Unidos, sobretudo por parte do acervo de fundações existentes naquele país. Já o patrocínio consiste na transferência de recursos para a produção e realização de bens e serviços (shows, eventos, gravação de $C D s, \quad D V D s$, apresentação de peças teatrais, espetáculos de dança, realização de filmes e/ou documentários, entre outros) culturais mediante fins promocionais que gerem retorno institucional para o patrocinador. O patrocínio é a modalidade mais utilizada no âmbito das leis de incentivo cultural. Por fim, o investimento se baseia na transferência de recursos para produtos culturais, buscando participação direta nos lucros auferidos pelos bens e serviços culturais.

As seis maiores empresas incentivadoras em 2008 possuem departamentos e/ou setores específicos de cultura, cuja função, além de coordenar a execução das políticas culturais da empresa, é realizar e acompanhar as três etapas antes descritas da lei Rouanet. Tanto esses departamentos quanto o produtor cultural que oferece seus serviços às empresas, ou seja, os proponentes devem dominar todo processo contábil da empresa no qual está inscrito o projeto. $\mathrm{O}$ imperativo desse controle criou a necessidade de contratação de profissionais com trânsito entre as áreas contábil e cultural, engendrando um novo tipo de profissional: o contador cultural, ou seja, um profissional com domínio suficiente das técnicas contábeis e dos mecanismos de tributação existentes nas duas principais leis de incentivo. Para subsidiar esses profissionais algumas empresas, como os bancos Bradesco e Itaú ${ }^{7}$, têm publicado trabalhos acerca de todo o processo de captação de recursos, explorando não apenas as três etapas mencionadas antes, mas também as pequenas fases de tramitação e circulação dentro de cada uma das três etapas maiores ${ }^{8}$.

$\mathrm{Na}$ primeira etapa de tramitação dos projetos, o proponente deve indicar um dos segmentos culturais e artísticos no qual o projeto pretende obter o incentivo. O Fundo Nacional de Cultura e as principais leis de incentivo que formam o mecenato, que perfazem no seu conjunto a legislação federal de incentivo à cultura, estabelecem sete grandes setores culturais e artísticos. Os sete segmentos definidos pela legislação federal passaram a ser seguidos pelas demais leis de incentivo criadas nos estados e municípios. Segundo dados do Instituto Pensarte e do próprio Ministério da Cultura $^{9}$, dos segmentos classificados pela legislação federal, até 2004, o segmento das artes cênicas apresentou o maior percentual de projetos incentivados $(17,62 \%)$, seguido de perto pelo segmento da música $(16,58 \%)$, antecedidos pelos segmentos literatura $(12,44 \%)$, produção audiovisual $(11,92 \%)$ e patrimônio cultural (11.33\%). Essa segmentação é também seguida pelas grandes empresas que dispõem de 
recursos próprios, isto é, não originários das leis de incentivo (mecenato) e do Fundo Nacional de Cultura (FNC), como a Petrobrás e a Vale do Rio Doce.

Após alguns messes de debate, conduzido e coordenados pelo Ministério da Cultura, que realizou conferências estaduais e uma consulta pública no sitio do ministério, o governo federal apresentou, em novembro de 2010, um novo projeto de lei destinado ao financiamento da produção cultural brasileira, reformando substancialmente a Lei Rouanet, cujo nome oficial, caso o projeto venha de fato a ser aprovado, passa a ser Programa Nacional de Fomento e Incentivo à Cultura - Profic. No dia 08 de dezembro de 2010 a Comissão de Educação e Cultura da Câmara dos Deputados aprovou o texto da nova lei, que seguiu para a apreciação no Senado e demais passos regulares de tramitação. A proposta cria novas modalidades de incentivo e estabelece novas alíquotas, faixas de desconto $(30 \%$, $60 \%, 70 \%, 80 \%$ e $100 \%$ ), para o imposto devido e seu desconto e utilização junto a uma ação e/ou projeto cultural, além da permissão de inclusão nos projetos financiado do montante de até $15 \%$ com despesas administrativas. No corpo do novo texto da lei institui-se também o novo Fundo Nacional de Cultura (FNC), que terá, no mínimo, $50 \%$ de todos os recursos da união destinado à cultura, além de destinar que $80 \%$ do fundo serão destinados aos proponentes culturais que integram a sociedade civil, ou seja, não vinculados a patrocinadores e a entidades dos poderes públicos municipais e estaduais, assim como veda a utilização de recursos do fundo para o pagamento de despesas correntes (folha de pagamento e custos administrativos) por parte dos três níveis governamentais. A proposta cria ainda doze categorias e/ou linguagens artístico-culturais específicas que podem ser financiadas: Artes visuais; teatro; circo; dança; música; acesso e diversidade; patrimônio e memória; livro, leitura, literatura e língua portuguesa; ações transversais e equalização de políticas culturais;audiovisual; culturas populares e de museus e memórias.

Segundo o ex-ministro da cultura Juca Ferreira, a proposta busca fundamentalmente seguir dois princípios: promover a descentralização dos recursos captados através dos mecanismos de financiamento e ampliar significativamente as formas de acesso, exigindo dos maiores captadores dos recursos um política de acesso, sobretudo mediante preços módicos. Segundo o ex-ministro, quanto maior o recurso público envolvido/captado maior a exigência de gratuidade e acessibilidade. Durante o exercício de 2010, 2.248 proponentes buscaram captar recursos junto a Lei Rouanet. Desse total, cinco proponentes destacaram-se na captação de recursos junto às empresas incentivadoras, representando apenas $0,22 \%$, que correspondeu por parte desses cinco proponentes 14 projetos culturais. Esses projetos, por sua vez, captaram cerca de $\mathrm{R} \$ 82$ milhões, o que representou cerca de 7,2\% de todos os recursos captados naquele ano, que alcançou a ordem de $\mathrm{R} \$ 1$ bilhão e 140 milhões. Como se pode depreender, sobretudo se esses valores forem cotejados com os dados apresentados antes, há um grau acentuado de concentração de recursos captados por alguns proponentes e, respectivamente, por alguns projetos realizados. Sem embargo, tal grau de concentração deriva dos dispositivos jurídicos e financeiro-operacionais presentes na lei, mas também do alto grau de especialização (departamentos, gestores, contadores culturais, administradores culturais, consultores, entre outros) do trabalho de obtenção e captação de recursos assumidos por alguns proponentes, que encabeçam a lista dos grandes captadores em 2010. 
O maior captador da lei Rouanet em 2010 foi o Instituto Itaú Cultural (R\$ 26,6 milhões), que mantém uma regular atividade artístico-cultural concentrada nas artes visuais e artes integradas. 0 instituto captou esse montante através das dez principais empresas que compõem o grupo financeiro Itaú. Em segundo aparece a Fundação Bienal de Arte de São Paulo (cerca de R 17 milhões), que destinou boa parte dos recursos para a realização da $29^{a}$ Bienal de Arte de São Paulo, que em 2010 completou sessenta anos de existência. O restante da lista dos dez maiores captadores em 2010 é assim composta: H Melillo Comunicação (R\$ 13,3 milhões); Masp (R\$12,7 milhões); Teatro Municipal do Rio de Janeiro $(R \$$ 12,3 milhões); Orquestra Sinfônica Brasileira (R\$ 12, 1 milhões); Orquestra Sinfônica do Estado de São Paulo (R\$ 10,5 milhões); T4F Entretenimento (R\$ 10,1 milhão); Associação Pró-musica (R\$ 9,7 milhões) e Fundação Vale do Rio Doce (R\$ 9,3 milhões $)^{10}$. Salta aos olhos nessa lista, por um lado, a localização dos dez principais proponentes, o Sudeste do país; por outro lado, a ausência da companhia Petrobras. As razões para a existência do primeiro aspecto são sobejamente conhecidas, já as razões da segunda serão objeto de reflexão à frente.

Como resultado da consolidação institucional e financeira das leis de incentivo, durante os primeiros anos da década passada, foi recrudescido o processo de criação de leis de incentivo no âmbito estadual e municipal. Praticamente todos os estados da Federação possuem hoje algum instrumento legal de incentivo à produção cultural. Segundo o SESI, dos 26 estados brasileiros e mais o Distrito Federal, 13 possuem leis específicas de incentivo, sendo que 10 possuem também fundos específicos de cultura e outros sete possuem leis e fundos (sendo o fundo um artigo específico da lei de incen- tivo, como nos casos dos Estados do Ceará e Paraíba). Existem também os estados que abrigam sistemas estaduais de cultura, nos quais aparecem planos integrados entre regiões e municípios, como nos casos dos estados de Pernambuco, Piauí e Ceará. Por fim, existem ainda os estados que possuem leis de incentivo vinculadas a outros setores (educação, esporte, etc.), como os estados do Espírito Santo e Acre.

No que diz respeito aos municípios $^{11}, 18$ das 26 capitais estaduais brasileiras possuem algum mecanismo legal de incentivo, sendo a maioria leis que incorporam a existência de fundos próprios, com recursos advindos do IPTU. Segundo o inventário realizado pelo SESI ${ }^{12}$, a região Sudeste apresenta a maior densidade (secretarias municipais e estaduais, leis de incentivo e/ou lei de fundo, fundações culturais e institutos) institucional direcionada à esfera cultural, seguida pela região Nordeste. De acordo com o referido inventário, os estados nordestinos aparecem bem colocados em um ranking geral de classificação nacional. Os critérios de classificação do ranking levaram em conta a execução orçamentária dos órgãos estaduais da administração cultural e a movimentação financeira total em torno da rubrica cultura (leis de incentivo e fundos). Nesse ranking o estado de São Paulo ocupa a primeira colocação, seguido pelo Estado do Rio de Janeiro. O Estado da Bahia ocupa a $5^{\mathrm{a}}$ colocação, Pernambuco a $8^{a}$ e o Ceará a $9^{a}$ posição. Esses três últimos estados juntos ocupam uma posição de grande relevo no ranking nacional, pois engendraram, desde o início dos anos noventa, leis de incentivo que serviram de modelos para outros estados da federação.

A Bahia, por exemplo, apresentou ao longo dos últimos anos um aumento substancial da sua execução orçamentá- 
ria, ou seja, os recursos destinados a programas e projetos que compõem as políticas culturais do estado, apresentando uma média de crescimento anual de cerca de $0,76 \%$, que totalizou no período de 1985 a 2005 um crescimento de $15,42 \%$, contra uma média anual nacional no mesmo período de $0,04 \%{ }^{13}$. Um dos responsáveis diretos por esse crescimento foi à instituição do programa estadual Fazcultura, criado em 1996. O programa atua como um fundo, semelhante ao Fundo Nacional de Cultura (FNC), cujas origens dos recursos vêm de parcelas do ICMS (Imposto Sobre a Circulação de Mercadorias). Durante os onze anos de vigência do programa, o setor cultural nomeado pela Secretaria de Cultura e Turismo de tradições populares foi o que apresentou maior número de projetos patrocinados, $31,8 \%$ do total. Pernambu$\mathrm{co}, 8^{\mathrm{a}}$ colocado no ranking estabelecido pelo SESI, dispõe de quatro leis específicas de incentivo à cultura (Lei 11.005, de 1993, Lei 11.914, de 2000, Lei 12.310, de 2002 e Lei 12.629 de 2004), todas complementares entre si e integradas ao principal fundo de cultura do estado, o FUNCULTURA. O Ceará, por sua vez, apresenta também uma sólida legislação de incentivo, cujo núcleo é a Lei Jereissati, que estabeleceu o FEC (Fundo Estadual de Cultura). A lei Jereissati destina recursos para incentivos nos segmentos de cinema, vídeo, música, artes plásticas e gráficas, artes cênicas, artesanato, folclore, filatelia, patrimônio histórico e artístico. Já o FEC destina recursos preferencialmente para as áreas de patrimônio imaterial, produções de grupos populares e associações comunitárias.

Em 2003 o Instituto Cultural Cidade Viva em parceria com a Universidade Federal Fluminense (UFF) publicou um minucioso trabalho acerca do perfil das empresas patrocinadoras da cultura no Brasil $^{14}$. O trabalho traz um conjunto signi- ficativo de dados acerca das empresas, obtidos através de um questionário aplicado entre 2002 e 2003, que foi aplicado durante etapas distintas da pesquisa. $O$ questionário buscou levantar o perfil das principais empresas patrocinadoras de cultura, através de perguntas diretas e estruturadas em torno de tópicos, como leis de incentivo, intenções do patrocínio, setor cultural, entre outros. Segundo a pesquisa, do total de 431 empresas selecionadas, cerca de $65 \%$ responderam que a principal razão pela qual investem em cultura é o ganho institucional da empresa, ou seja, o ganho de imagem da marca da corporação. O segmento econômico que mais investe cultura é o industrial, respondendo por cerca de $28 \%$ do total de recursos, entre doações, patrocínios e apoios, seguido do setor de serviços, com $21,31 \%$. 24,19\% das empresas entrevistadas atuam na região Sudeste, outras $21,51 \%$ têm suas atividades concentradas na Região Nordeste. As leis de incentivo fiscal mais utilizadas são a lei Rouanet $(35 \%)$, as leis estaduais do ICMS (imposto sobre circulação de mercadorias), com $31,25 \%$, a lei do ISS (imposto sobre prestação de serviços), com $20 \%$, e a Lei do Audiovisual (13,75\%).

A pesquisa mostra que a principal motivação empresarial é de cunho publicitário, isto é, a atuação da empresa junto ao universo simbólico e cultural pode desembocar em um substancial ganho de imagem. Esse ganho de imagem não é imediato, faz parte de um processo de construção de um diálogo aberto entre a marca e seus consumidores, fornecedores e investidores, ou seja, de um processo sistemático de gestão da marca. O autor do texto de apresentação da pesquisa, Fernando Portela, chama atenção para que o diálogo entre marca e público mediado pela cultura (ou seja, pelos profissionais culturais que desenvolvem bens e serviços simbólicos) faz parte de 
um movimento maior de tomada de posição empresarial que ainda está muito embrionário, mas que aponta para uma tendência certa. O autor chama atenção para a necessidade de se desenvolver uma consciência empresarial dirigida para o bem-estar coletivo, cujo caminho passa inevitavelmente pela promoção da diversidade, da diferença e da criatividade.

As reflexões de Portela trazem o imperativo ético de transformação da consciência empresarial, deslocando o objetivo imediato do lucro, isto é, lastreado apenas na redução dos custos e massificação das vendas, para um diálogo mais íntimo com o consumidor, para uma espécie de construção de uma legitimidade da marca capaz de produzir novas estimas por parte de consumidores, fornecedores e gestores da marca. A rigor, se pretende que as empresas não produzam tão-somente bens e serviços, mas, sobretudo, valores e éticas de vida (PORTELA, 2003).
Muitas mudanças estão ocorrendo ou vão ocorrer dentro das empresas nos próximos anos. Elas acarretarão o nível de consciência de grande número de empresários e conseqüentemente crescerá o patrocínio nas áreas cultural e social. Chamamos atenção para a abertura de novas oportunidades de trabalho para agentes culturais, conscientes de seu papel de agentes da mudança. (...) Empresas preocupadas com toda sociedade investirão em projetos culturais, inclusive com ações nas áreas de baixa renda e também assumirão responsabilidades maiores em relação à ecologia e à educação. Daqui a dez anos poucas serão as empresas que sobreviverão no mercado se não tiverem essa consciência, se não descobrirem que seus papéis principais não são gerar emprego e lucro, mas sim trabalho e consciência para construir um mundo

\section{Gráfico 01 - 0 que leva as Empresas a investir?}

Ganho de imagem institucional

Agregação de valor à marca da empresa

Reforço do papel social da empresa

Benefícios fiscais
Retorno de mídia

Aproximação do público-alvo

Outros

Não citaram

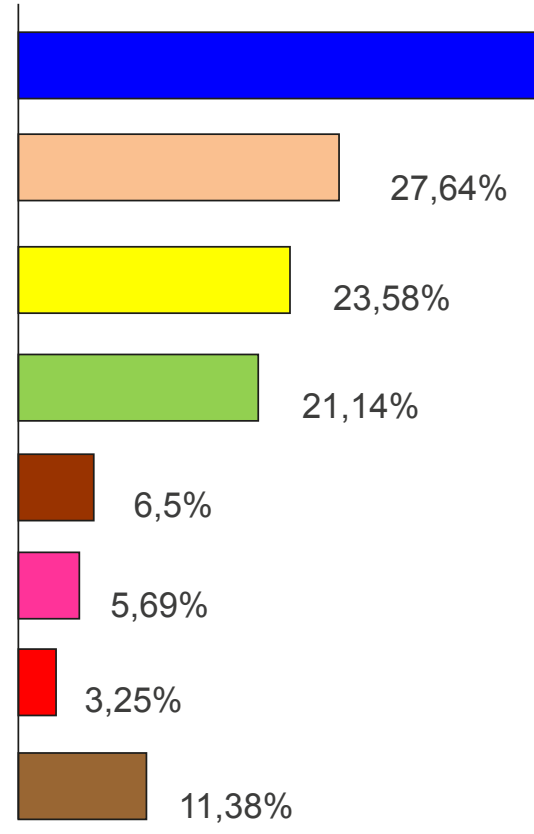


melhor. (...) A nova empresa, na era do conhecimento e da emoção, é aquela que enxerga o valor da marca e sabe que é preciso planejar o investimento nas áreas culturais, sociais, esportivas, educacionais e outras dependendo do seu foco. Sabe que precisa fazer isso sem mentiras, de forma planejada, independente ou não de haver incentivos fiscais (...) Nosso cliente é aquele que tem uma imagem positiva do nosso trabalho e do nosso produto, mesmo que nunca tenha assistido a nossa peça de teatro ou um par dos sapatos que fabricamos (...) A nova empresa deixa aos poucos de ser patrocinadora e se transforma em parceira, o que significa dizer que passa a se envolver nos projetos, a discutir orçamentos, conteúdos, possibilidades de retorno e garantias, nem que faça isso através de produtores terceirizados. Isso acontecerá na medida de seus interesses e de sua responsabilidade sociocultural. (PORTELA, 2003)

A despeito do tom marcadamente profético de Portela, é possível sustentar que o diálogo entre marca e público (consumidores, trabalhadores, acionistas, fornecedores, entre outros) procura se realizar mediante a construção de políticas culturais privadas que não seriam possíveis sem as leis de incentivo à cultura. No entanto, como o texto da citação acima pode demonstrar, o adiamento do grande lucro imediato através da formação de uma consciência que exige a destinação de recursos (ainda que decorrente da renúncia fiscal pública) para a cultura produz um capital de prestígio simbólico-cultural que faculta à empresa uma lucratividade posterior muito maior. Os dividendos dessa lucratividade a médio e longo prazo reverberam, pois, em formas de prestígio cristalizadas em títulos (selos, prêmios, concursos, entre outros) como o título de empresa "culturalmente responsável" ou "empresas amigas da cultura", conferidos por organizações e instituições da administração cultural pública.

A Secretaria de Cultura do Estado do Ceará (SECULT), por exemplo, concede, desde 2004, o selo de responsabilidade cultural. O selo é concedido às empresas que participam diretamente (como doadoras e/ou incentivadoras) ou indiretamente da promoção e valorização da cultura do Estado. A partir de ações e programas nas quais as empresas se envolvem em cada ano, a Secretaria da Cultura avalia e elege as empresas que merecem figurar nas campanhas promocionais e publicitárias oficiais do estado. Nos documentos, panfletos e cartilhas publicados pela secretaria no primeiro semestre de 2008 aparecem a peça publicitária do selo com os seguintes dizeres no cabeçalho: "selo de responsabilidade cultural 2007: um prêmio para as instituições que acreditam na força da cultura cearense". As empresas premiadas têm o direito, por sua vez, de exibir em suas campanhas publicitárias a marca do selo de responsabilidade cultural do estado, que apresenta os seguintes dizeres: esta empresa tem responsabilidade cultural.

O selo foi criado por meio da Lei $n^{\circ}$ 13.426/2003, com o objetivo definido de estabelecer uma forma de reconhecimento público para as pessoas jurídicas de direito público ou privado, com ou sem fins lucrativos, que de alguma formam apóiam a cultura do estado. A sistemática operacional de concessão do selo é baseada em três etapas distintas: a primeira é a avaliação inicial da empresa (missão, valores, objetivos, resultados, ações culturais desenvolvidas pela organização); a segunda etapa consiste em apreciar o material apresentado e organizado pela empresa por parte de uma comissão avaliadora independente da 
Secretaria de Cultura do Estado, que se desloca até as empresas para conferir a veracidade das informações fornecidas; por fim, na terceira, é montado um ranking de pontuação no qual a empresa pleiteante do selo passa a figurar em uma determinada posição, onde são levados em consideração aspectos como o montante de investimentos destinados à cultura do Estado e as ações empreendidas.
A primeira premiação do selo foi realizada em 2004, quando foram premiadas 15 organizações, em quatro categorias. A partir de então, alguns ajustes foram sendo realizados pela Secult/Ceará, como a ampliação de categorias e dentro do próprio processo de seleção. A partir de 2005 o número de empresas concorrentes aumentou significativamente e, a partir de então, a política do selo passou a interes-

Tabela 02 - Relação de organizações agraciadas com o Selo de Responsabilidade Cultural 2004, 2005 e 2006

\begin{tabular}{|c|c|c|c|}
\hline Categorias & Selo 2004 & Selo 2005 & Selo 2006 \\
\hline \multirow{3}{*}{ Empresarial } & $\begin{array}{l}\text { Pequeno porte: } \\
\text { - Condomínio Shopping Benfica } \\
\text { - Clínica Dra. Maria Helena } \\
\text { Magalhães de Albuquerque }\end{array}$ & $\begin{array}{l}\text { Pequeno porte: } \\
\text { - Condomínio } \\
\text { Shopping Benfica }\end{array}$ & $\begin{array}{l}\text { Micro e Pequeno porte: } \\
\text { - Espaço Cultural Arre Égua }\end{array}$ \\
\hline & $\begin{array}{l}\text { Médio porte: } \\
\text { - E.I.M. Empreendimentos } \\
\text { Industriais e Montagens } \\
\text { - Servis Segurança LTDA } \\
\text { - Tintas Hidracor }\end{array}$ & $\begin{array}{l}\text { Médio porte: } \\
\text { - Servis Segurança } \\
\text { LTDA }\end{array}$ & $\begin{array}{l}\text { Médio porte: } \\
\text { - Shopping Benfica }\end{array}$ \\
\hline & \begin{tabular}{|l|} 
Grande porte: \\
- Companhia Energética do \\
Ceará - Coelce \\
- Agripec Química e Farmacêuti- \\
ca S/A \\
- Expresso Guanabara S/A
\end{tabular} & $\begin{array}{l}\text { Grande porte: } \\
\text { - Companhia } \\
\text { Energética do } \\
\text { Ceará - Coelce }\end{array}$ & \begin{tabular}{|l|} 
Grande porte: \\
- Servis Segurança
\end{tabular} \\
\hline \multirow{2}{*}{ Pública } & \multirow{2}{*}{$\begin{array}{l}\text { - Prefeitura Municipal de } \\
\text { Guaramiranga } \\
\text { - Banco do Brasil S/A } \\
\text { - Caixa Econômica }\end{array}$} & \multirow[t]{2}{*}{$\begin{array}{l}\text { - Banco do Nordeste } \\
\text { do Brasil }\end{array}$} & $\begin{array}{l}\text { Empresarial Pública: } \\
\text { - Caixa Econômica } \\
\text { Federal }\end{array}$ \\
\hline & & & $\begin{array}{l}\text { Governamental: } \\
\text { - Prefeitura Municipal } \\
\text { de Senador Pompeu }\end{array}$ \\
\hline Institucional & $\begin{array}{l}\text { - Sebrae Ceará } \\
\text { - Instituto Pão de Açúcar } \\
\text { - Serviço Social do Comércio - } \\
\text { SESC }\end{array}$ & $\begin{array}{l}\text { - Serviço Social } \\
\text { do Comércio - SESC }\end{array}$ & $\begin{array}{l}\text { - EDISCA - Escola de } \\
\text { Dança e Integração } \\
\text { Social para Crianças } \\
\text { e Adolescentes }\end{array}$ \\
\hline Diamante & - Banco do Nordeste do Brasil & - Banco do Brasil & - Banco do Nordeste do Brasi \\
\hline $\begin{array}{l}\text { Destaque } \\
\text { Interior }\end{array}$ & - & - & $\begin{array}{l}\text { - Fundação Casa Grande - } \\
\text { Memorial do Homem Kariri }\end{array}$ \\
\hline $\begin{array}{c}\text { Destaque } \\
\text { Empreendedora }\end{array}$ & - & - & $\begin{array}{l}\text { - Pão de Forno Indústria de } \\
\text { Alimentos }\end{array}$ \\
\hline
\end{tabular}

Fonte: GUILHERME (2006); SILVA (2007) 
sar outros estados da região Nordeste e a própria União. Acerca da concessão do selo, o então ministro da Cultura, Gilberto Gil, destacou: "o Ceará está nos oferecendo a inspiração e a tecnologia que nós queremos replicar pelo país inteiro. O apoio do Ministério da Cultura a está iniciativa é integral, até porque é imprescindível que esta ação seja disseminada pelo Brasil" (GIL, 2005).

A política do selo de responsabilidade cultural concedido pela Secult/Ceará está situada em uma ambiente maior de experimentações e inovações tecnocráticas e gerenciais ligadas à cultura realizadas no âmbito do Estado do Ceará. O estado foi o primeiro no país a possuir uma secretaria de estado destinada exclusivamente à cultura. Por meio da Lei $\mathrm{n}^{\circ}$ 8.541, de 09 de agosto de 1966 foi criada a Secretaria de Cultura do Estado do Ceará, sendo o primeiro secretário o escritor Raimundo Girão. Nesta década, em total consonância com a arquitetura institucional que passou a ser elaborada pelo sistema MinC a partir de 2003, o estado formulou o Sistema Estadual de Cultura, cujo objetivo seria integrar os 184 municípios cearenses à dinâmica de capilarização do Sistema Nacional de Cultura e às discussões acerca do conteúdo e implementação do Plano Nacional de Cultura (PNC). Seguindo essa senda, a Secult/Ceará instaurou durante o a no de 2007 o processo discursivo que desembocou na formulação da Constituição Cultural do Estado do Ceará. O processo de constituição desse documento envolveu um conjunto de discussões, fóruns municipais e assembléias, cujo ápice foi a Assembléia Popular Estadual, que contou com 127 delegados municipais. O evento foi constituído por artistas, intelectuais, pesquisadores, empresas, prefeituras, organizações não-governamentais, além dos próprios delegados municipais. A Assembléia Popular Estadual operou como uma constituinte cultural, cujo resultado foi a elaboração do documento legal da Constituição Cultural do Estado do Ceará, que alterou alguns dispositivos da Constituição do Estado do Ceará (promulgada em 1989) no tocante à cultura. O documento objetiva dotar o Estado de um planejamento de longo prazo para a cultura, privilegiando a cultura popular espraiada pelas principais regiões interioranas do Estado. A política de concessão do selo de responsabilidade cultural no Ceará, assim como a consecução da constituição cultural do estado, atesta o processo crescente de normatização e oficialização da esfera cultural, notadamente da cultura popular.

O diálogo contumaz da empresa com o universo de atores que, direta ou indiretamente, determinam a posição de prestígio da marca empresarial, exige que as corporações se inscrevam em um cenário mais largo de comunicação global, a partir do qual a organização aposta em posturas ligadas à consolidação dos valores caros aos atores responsáveis pela posição de prestígio ocupada pela empresa. Nesse sentido, as principais empresas envolvidas com programas e ações culturais buscam, cada uma a seu modo, tecer uma teia própria que assegure sua participação no concerto geral da chamada cidadania cultural no Brasil, que faz parte da arquitetura institucional montada no decurso da década passada pelo Ministério da Cultura, cujos insumos legais e discursivos travam uma interface estreita com o repertório discursivo UNESCO ${ }^{15}$. Nesses termos, as empresas buscam desenvolver uma espécie de cidadania cultural corporativa bastante interessada, ou seja, uma componente decisiva da gestão da marca empresarial. Em um ensaio intitulado Cultura: rebelde e ingovernáve/16, Zygmunt Bauman destaca, através de uma reflexão de Neomi Klein, que, em sua maioria, 
as grandes corporações industriais não produzem mais o que produziam antes e nem fazem mais publicidade do que produzem ou produziam, mas compram produtos homólogos e adicionam então sua marca. "A marca fixada no produto não agrega valor, mas é o próprio valor, o valor de mercado e, portanto, o único valor que conta, o valor em si". (BAUMAN, 2007, p.82).

\section{GESTÃO INSTITUCIONAL DA MARCA E POLIITICAS CULTURAIS PRÓPRIAS}

O selo de responsabilidade cultural, assim como as demais formas de reconhecimento oficial, agrega valor à marca empresarial. Esse valor é simultaneamente simbólico e econômico, os trânsitos entre um e outro, assim como a constituição de um e de outro, são dinâmicos e suas fronteiras tênues e imprecisas. Uma empresa que luta pela sustentação e utilização permanente desses selos e títulos públicos de reconhecimento é a Petrobras. A empresa mantém um conjunto de ações de incentivo à produção cultural. Desde o final da década passada a empresa lidera, de forma absoluta, a lista das maiores patrocinadoras, sendo a lei Rouanet o dispositivo legal mais utilizado pela companhia. Em agosto de 2008 a empresa renovou um conjunto de documentos que estabelecem cooperação técnica entre a empresa e o Ministério da Cultura, além de um elenco de convênios que criaram dez editais em diferentes áreas e segmentos que totalizam um investimento de R $\$ 28$ milhões. No entanto, o núcleo da política cultural da companhia diz respeito ao Programa Petrobrás Cultura/ ${ }^{17}$. O programa é baseado na publicação de editais públicos em áreas como cinema, artes cênicas, música, literatura e patrimônio imaterial. O programa apresenta uma estrutura organizacional baseada na seleção pública de proje- tos e na escolha direta, que totalizou em 2007 cerca de R\$ 160 milhões, distribuídas nas cinco regiões do país, sendo a região Sudeste, seguida pela região Nordeste, as que mais apresentam projetos e recebem recursos. No Nordeste, os Estados da Bahia, Pernambuco e Ceará são os que mais se destacam. O Programa Petrobrás Cultural se interessa por um conjunto de conteúdos e tem lançado mão dos mais diferentes suportes técnicos. O segmento do patrimônio cultural imaterial é um exemplo desse interesse diversificado. O programa tem patrocinado uma infinidade de CDs e DVDs portando os conteúdos das culturas populares espraiadas pelos rincões rurais do país, como o CD Alegremente cantando, produzido na zona rural da cidade de Vitória da Conquista, no sertão baiano, que traz 21 faixas de músicas de ternos de reis, ou o $C D$ que traz os cantos e repentes do concurso de cantadores e repentistas organizado pela Secretaria de Cultura de Pernambuco, em 2006. Os gestores e técnicos do programa, como se verá também no exemplo do Banco do Nordeste, inspiram-se nas políticas de patrimônio cultural imaterial implementadas no âmbito do Sistema Federal de Cultura, assim como uma compreensão de cultura popular marcada pela dimensão rural da experiência.

Embora o núcleo da política cultural da empresa seja o Programa Petrobras Cultural (PPC), a rigor, a companhia mantém também uma ação mais dilatada no que toca ao incentivo cultural. A empresa tanto dispõe de recursos financeiros próprios destinados aos incentivos culturais (que podem ser utilizados em ações mais regulares, que já possuem certa capilaridade e penetração junto aos profissionais da cultura, como o Programa Petrobrás Cultural), quanto dispõe também de recursos obtidos junto aos mecanismos de incentivo fiscal facultados 
pelas leis federais, como a lei Rouanet, que permitem a dedução de até $4 \%$ do total de impostos devidos pelas pessoas jurídicas. Por exemplo, em 2008 o aporte total de recurso à cultura foi da ordem de $\mathrm{R} \$ 205$ milhões, desses R\$ 166 foram provenientes das leis de incentivo, ou seja, de impostos não pagos, $4 \%$ do total de impostos devidos a união, o restante, $\mathrm{R} \$ 39$ milhões, foi derivado da própria receita, lucro, anual da empresa No exercício de 2010, como se pode constatas a partir da lista dos dez maiores captadores de recursos junto a Lei Rouanet, a empresa não figura entre os dez mais, mas tal ausência não significa que a empresa tenha reduzido seu interesse pelo financiamento da produção cultural. De certo, a companhia continua utilizando os dispositivos fiscais existentes, mas certamente tem aumentado o volume de recursos próprios direcionados ao financiamento da produção cultural. E mais, a ausência mencionada certamente decorre também do interesse do governo federal (já que as diretorias da companhia e a presidência são indicações governamentais) em reduzir a participação das empresas estatais no que toca a captação de recursos junto a atual lei Rouanet, buscando assim uma forma direta de minorar a operacionalização e legitimação da atual lei.

Na edição 2008/2009 os recursos do Programa Petrobras Cultural sofreram uma redução, passando para $R \$ 42$ milhões, voltando a se elevar na edição seguinte, 2010, alcançando $\mathrm{R} \$ 61,2$ milhões. A ambivalência público/privada assinalada antes aparece aqui com contornos bem definidos. O financiamento é privado porque ele é realizado pela empresa, embora as maiores empresas incentivadoras sejam de capital misto, ou seja, as próprias empresas (como a Petrobras e o Banco do Brasil) são simultaneamente públicas e privadas. Por outro lado, como se verá a partir do exemplo do $B N D E S$, algumas empresas estatais atuam simultaneamente em duas frentes do financiamento cultural. Agem como patrocinadoras (lançando mão das leis de incentivo fiscal) e como investidoras que, mediante empréstimos a terceiros ou empregando recursos diretos, buscam obter ganhos econômicos atra-

\section{Gráfico 02 - Evolução da verba total do Programa Petrobrás Cultural (R\$ milhões)}

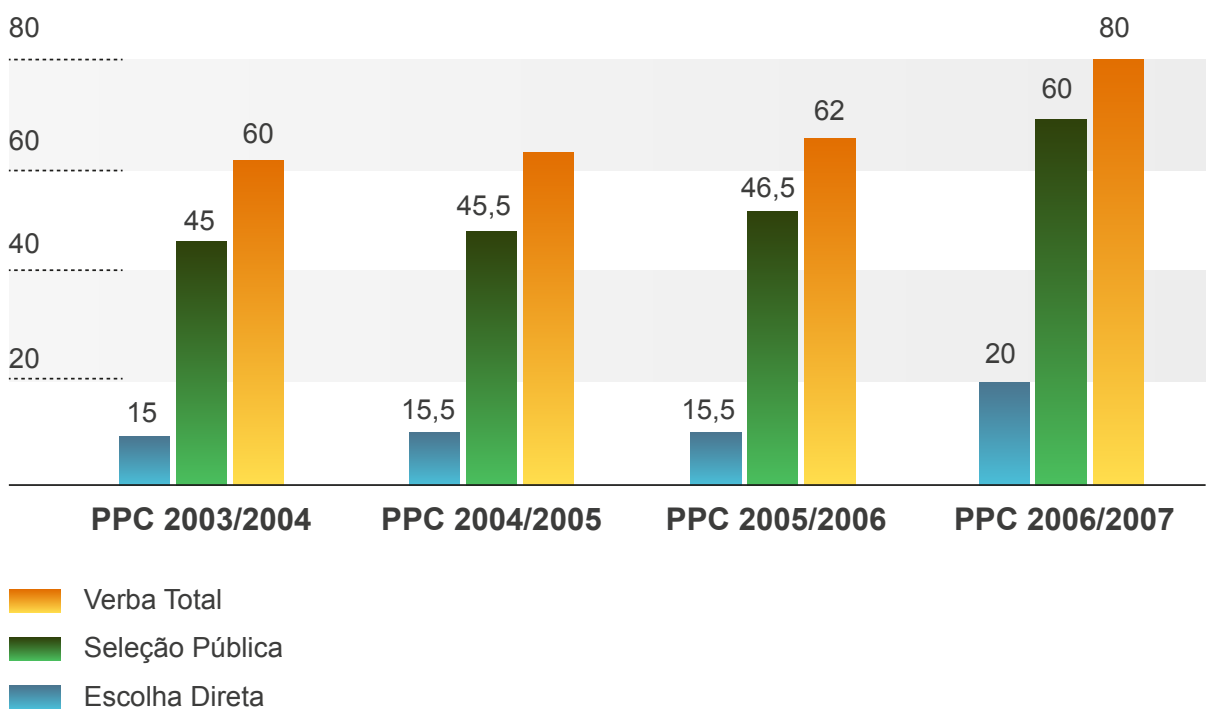


vés da produção cultural ${ }^{18}$. É a empresa que decide o que, como e onde produzir, segundo os direcionamentos e diretrizes internas da organização. Ao invés de pagar o imposto devido, isto é, o tributo que é cobrado pelo Estado em cima da taxa anual de lucratividade da empresa, a mesma apresenta o resultado da sua produção (um show, um evento teatral, um programa mais duradouro, enfim, algo que justifique o desconto de uma parcela) como forma de substituição do pagamento líquido do tributo. Ao mesmo tempo, os recursos são públicos, pois são oriundos de impostos e, portanto, do direito de tributação assegurado pela constituição, mas também têm uma origem privada, pois incidem sobre 0 lucro das empresas, o que envolve a sua capacidade de gestão empresarial, de atuação no mercado e de lucratividade, e, portanto, de competência econômico-financeira. Essa imbricação confere às leis de incentivo à produção cultural um caráter inteiramente ambivalente.

A ambivalência mencionada antes corroborou para a instauração de uma racionalidade administrativa e publicitária antes desconhecida na esfera cultural. As leis de incentivo, como de resto todo o modelo de produção e financiamento cultural, acentuaram o processo de expansão do mercado de bens simbólicos no Brasil ${ }^{19}$. Um dos vetores que permitiram essa expansão, e que hoje é parte constitutiva do mercado de bens simbólicos no país, diz respeito à montagem de um acirrado sistema de lutas em torno dos bens de prestígio que asseguram legitimidade empresarial às marcas. Como se evidenciou a partir da citação de Portela acima apresentada e da pesquisa realizada pela Universidade Federal Fluminense em parceria com o Instituto Cultural Cidade Viva ${ }^{20}$, tornou-se uma preocupação permanente (objeto regular de pesquisas internas nas corporações) por parte dos gestores públicos e privados a manutenção de uma boa imagem associada à marca da empresa, algo que passa necessariamente pela possibilidade de sustentação de determinados títulos e prêmios, como os títulos de empresa culturalmente responsável, conferido, por exemplo, pela Secretaria de Cultura do Estado do Ceará. A necessidade de gestão cultural da marca engendrou também a produção de subsídios teóricos e técnicos (como as reflexões apresentadas antes por Portela) capazes de guiar as ações das empresas no segmento cultural. Durante essa década, foram publicados diversos guias de captação de recursos, cartilhas de instruções, guias de gestão cultural das marcas, assim como sítios na Internet e demais mídias ${ }^{21}$.

Um exemplo que reclama um tratamento mais pormenorizado a esse respeito é fornecido pelas políticas culturais desenvolvidas pelo Banco do Nordeste. Em 2005 a instituição criou o Programa $B N B$ de Cultura. Um dos principais critérios estabelecido pelo Programa BNB de Cultura do Banco do Nordeste, e que acentua essa dinâmica de gestão da imagem empresarial junto a um mercado institucional de marcas no Brasil, diz respeito ao potencial ganho de imagem do Banco do Nordeste que o projeto pode promover. Os projetos submetidos à apreciação do programa devem apresentar alguma indicação nesse sentido, ou seja, devem vincular o conteúdo desenvolvido e a linguagem artística trabalhada à instituição patrocinadora e ao Programa BNB de Cultura. Em um dos trechos da entrevista concedida pelo coordenador do programa, Mário Nogueira ${ }^{22}$, o mesmo ressalta: "há também a variável de potencial de imagem do banco julgada pelo BNB. Os avaliadores tinham dificuldades porque diziam: 'rapaz nós somos artistas', aí agora é o banco, o pessoal da superintendência, os assessores, né, que vê se o 
projeto tem esse potencial de levar a imagem do banco lá pra a frente". Levar a imagem do banco "lá para a frente" significa adicionar aos produtos e atividades financeiras do banco os signos e temas da cultura popular sertanejo-nordestina, isto é, significa aproximar, ou mesmo fundir, a imagem do banco com os conteúdos, expressões e manifestações da cultura popular sertanejo-nordestina.

O Programa BNB de Cultura ${ }^{23}$, desde a sua primeira edição em 2005 até a última, em 2011, disponibilizou cerca de $\mathrm{R} \$ 16$ milhões para as áreas de literatura, música, artes cênicas, artes visuais, audiovisual e artes integradas, com base na captação de recursos mediante os editais de concorrência pública. Foram contemplados, nas cinco edições anuais do programa, 1.131 projetos, realizados em 474 municípios. Para a edição 2011 do programa, dessa vez em co-realização com o BNDES (Banco Nacional de Desenvolvimento Econômico e Social), o edital prevê a liberação de $\mathrm{R} \$$ 6 milhões. O edital deste ano (Edital do Programa BNB de Cultura - Edição 2011 - Parceria BNDES) estabelece três critérios norteadores para seleção final: $50 \%$ dos projetos contemplados serão destinados para municípios que apresentem um Índice de Desenvolvimento Humano (IDH) inferior a média geral do Nordeste e/ou Índice de Exclusão Social (IES) superior a média geral nordestina; $25 \%$ do total de projetos contemplados serão destinado àqueles municípios inseridos nos territórios da cidadania ${ }^{24} ; 50 \%$ no mínimo dos recursos serão direcionados aos proponentes sem fins lucrativos. O programa está organizado a partir de um edital anual de seleção de projetos culturais, que se inscrevem em uma das áreas listadas e, uma vez aprovados, se habilitam (de acordo com os procedimentos financeiros estabelecidos pelo banco) para receber os recursos.
O programa integra às ações da instituição aquilo que a mesma nomeia de ambiente da cultura. Seguindo uma tendência das instituições de serviços financeiros, tal qual destacado por Chin-Tao Wo (2006) ao pesquisar os Estados Unidos e a Grã-bretanha, e também seguida no Brasil ${ }^{25}$, o Banco do Nordeste criou os centros culturais de Fortaleza, $\mathrm{CE}$, de Souza, PB, e do Cariri, região semi-árida localizada na fronteira dos Estados do Ceará, Piauí e Pernambuco. Os três Centros Culturais do Banco do Nordeste (CCBNBs) dinamizam a circulação dos bens e serviços culturais na região Nordeste, pois, como se verificou antes, operam como equipamentos culturais que abrigam diversas atividades artístico-culturais. Os centros possuem orçamentos próprios e dispõem de calendários de programação divulgados pelas peças e campanhas publicitárias do banco nas três micro-regiões que sediam os centros. Durante o ano de 2007 os recursos para os centros totalizaram $R \$$ 7,5 milhões, alcançando um público total, desde a criação do primeiro centro em Fortaleza, de mais de três milhões de pessoas $^{26}$. Associado ao Programa BNB de Cultura e aos centros culturas, o banco disponibiliza no âmbito do Crediamigo (programa de micro-crédito produtivo da instituição) setores que podem receber recursos, como, por exemplo, artesanato, bandas de música, projeção de filmes, entre outros. Essas três ações compõem a política cultural do BNB.

O Banco do Nordeste é uma instituição financeira múltipla criada em 1952, que atua como uma sociedade de economia mista de capital aberto, sendo o maior acionista e controlador direto o governo federal ( $94 \%$ do capital acionário). Hoje a instituição está vinculada ao Ministério da Fazenda como uma instituição de fomento e crédito regional. Possui 5726 funcionários, 181 agências, atendendo a 1989 
municípios e 11 estados. O banco atua como instituição creditícia nas seguintes áreas: fruticultura, grãos, indústria, serviços, agricultura familiar, apicultura, pecuária, carcinocultura, comércio, floricultura, artesanato, turismo e cultura. Essas três últimas apresentam estreitas interfaces para a conformação da economia da criatividade na região Nordeste e suas respectivas indústrias da criatividade.

A política cultural da instituição é baseada na seleção pública através de editais. No que toca ao Programa BNB de Cultura, o edital do programa é acompanhado de oficinas de esclarecimento e divulgação do programa, realizadas pelos técnicos do banco ligados ao programa nas cidades, estados e regiões atendidas pelo banco. As oficinas são reuniões de instrução e preparação junto aos grupos de artistas e intelectuais (na maioria das vezes associações, entidades e organizações de artistas, produtores, músicos, atores, etc.), isto é, os proponentes, ligados à cultura popular sertanejo-nordestina. Dessas etapas, duas se destacam. Primeiro, o calendário, que esta- belece todos os passos do processo de tramitação dos projetos; segundo, o julgamento, que consiste na aferição de notas por parte de uma comissão julgadora (composta por profissionais de cada uma das seis áreas artístico-culturais do programa) que contratada pelas representações do banco nos nove estados nordestinos, e mais as regiões norte dos Estados do Espírito Santo e Minas Gerais. Além das etapas, o programa estabelece, assim como os projetos submetidos à liberação de recursos junto às leis Rouanet e do audiovisual, três fases de filtragem: apresentação, habilitação e seleção.

O Programa BNB de Cultura está estruturado a partir de quatro eixos estratégicos: a valorização da cultura regional nordestina, o acesso democrático aos bens e serviços culturais gerados, transparência no controle e fiscalização dos recursos concedidos e a produção de resultados positivos para a população nordestina. De 2005 a 2008 o programa atendeu a 328 cidades, concedendo recursos a 681 projetos culturais. Os quatro eixos de sustentação do programa

Tabela 03 - Edição 2007 do Programa BNB de cultura

\begin{tabular}{|c|c|c|}
\hline Estado & Habilitados & Selecionados \\
\hline AL & $5,0 \%$ & $4,5 \%$ \\
\hline BA & $16,7 \%$ & $14,1 \%$ \\
\hline CE & $19,3 \%$ & $13,4 \%$ \\
\hline ES & $2,5 \%$ & $1,0 \%$ \\
\hline MA & $7,5 \%$ & $8,3 \%$ \\
\hline MG & $7,6 \%$ & $4,5 \%$ \\
\hline PB & $8,9 \%$ & $6,9 \%$ \\
\hline PE & $18,8 \%$ & $12,7 \%$ \\
\hline PI & $7,0 \%$ & $3,8 \%$ \\
\hline RN & $14,6 \%$ & $7,7 \%$ \\
\hline SE & $6,4 \%$ & $4,9 \%$ \\
\hline
\end{tabular}

Fonte: Programa BNB de Cultura 
guardam uma relação direta com o repertório UNESCO. Esse, como já se viu, porta uma teia discursiva que opera como um norte de justificação das políticas culturais em boa parte do mundo, notadamente nos chamados países em desenvolvimento (UNESCO/MinC, 2008). Na entrevista realizada com o coordenador do Programa $B N B$ de Cultura, Mário Nogueira $^{27}$, o mesmo abre a sua fala acerca do programa enfatizando da seguinte maneira o seu primeiro eixo organizacional e operacional:

Então, quando foi em 2005, o banco criou o programa BNB de cultura, que foi baseado em quatro pilares. $O$ primeiro pilar dele é focar a cultura regional nordestina. Quer dizer, hoje o banco atua, além de todos os Estados do Nordeste, ele atua também no Norte de Minas Gerais e o Norte do Espírito Santo que também têm características do Polígono das Secas. Aí os projetos desse programa, eles devem ser focados na região nordestina ou no Norte de Minas e do Espírito Santo. Isso aí não significa dizer que pessoas de outras regiões e outros estados não possam participar, agora só que o peso é menor. Agora se a pessoa, por exemplo, na região Sul quiser fazer um trabalho sobre a cultura nordestina para ser disseminada lá, ai o peso é o mesmo de se fazer um trabalho na região Nordeste. (NOGUEIRA, 2008)

O que Nogueira destaca é que o Banco criou como um dos eixos prioritários de organização e operacionalização do programa para a valorização da cultura popular sertanejo-nordestina. As seis linguagens selecionadas pelo programa (artes cênicas, artes visuais, artes integradas, audiovisual, música e literatura) mobilizam diretamente os conteúdos daquilo que, ao longo do processo de moderniza- ção nacional, se convencionou chamar de cultura popular nordestina. Por exemplo, na categoria artes cênicas (a primeira com o maior número de projetos apresentados e aprovados) predominam projetos teatrais inspirados na literatura de cordel, ou seja, no vasto repertório de estórias populares disseminadas através dos folhetos de cordel. Na categoria música, por seu turno, predomina o gênero musical forró-baião, que compõe a montagem dos festejos juninos (muito presente também na categoria artes integradas).

A necessidade da vigilância permanente quanto às classificações envolvendo as linguagens artísticas e suportes físicos ganha aqui maior clareza. Embora o programa não setorize a cultura popular ou as tradições populares (como fazem alguns programas ${ }^{28}$ ), criando uma classificação específica ${ }^{29}$ para agregar os conteúdos produzidos por esses setores, a prioridade do programa é a promoção e fomento dos conteúdos classificados e legitimados como representantes "genuínos" da cultura popular sertanejo-nordestina. Assim, as linguagens travam um diálogo direto com certos conteúdos e aspectos das narrativas identitárias sertanejo-nordestinas. Outra exigência do programa, que reforça o primeiro pilar destacado por Nogueira, é que os projetos devem partir de municípios com até cem mil habitantes. Segundo o IBGE ${ }^{30}$, cerca de $35 \%$ da população nordestina vive em cidades com até 100 mil habitantes. É fácil perceber que o filtro estabelecido pelos técnicos e gestores do programa compreende que a cultura popular e/ou regional possui um vínculo direto com a dimensão rural, e que essa dimensão deve ser privilegiada nas políticas culturais da instituição - tanto no que diz respeito à dinamização de um mercado de bens simbólicos associado à marca do banco nesses municípios, quanto à possibilidade complementar de nutrir os processos criativos nesses locais. 
Cerca de $70 \%$ dos projetos apresentados junto ao programa são apresentados por pessoas jurídicas. São associações de artistas, entidades culturais, prefeituras, secretarias estaduais de cultura, clubes de cinema, sindicatos de atores, centros culturais, sociedades de amigos da cultura, entre muitos outros, que se habilitam e concorrem em uma das seis categorias. Há uma rede, concentrada principalmente nos estados do Ceará, Bahia e Pernambuco, de profissionais da cultura ligados à cultura popular sertanejo-nordestina, cuja tessitura depende do grau de interdependência entre os três eixos de organização da economia da cultura no Brasil. Os três eixos concorrem, como se verificou na primeira seção deste capítulo, para o recrudescimento do processo de profissionalização da cultura no Brasil, agora a profissionalização da cultura popular sertanejo-nordestina. O Programa BNB de Cultura, nesse sentido, opera como uma síntese entre os eixos de organização dessa economia. Como empresa controlada pelo Estado, o banco produz, consome e promove (mediante seus centros culturais) a circulação de bens e serviços culturais que portam aspectos da cultura regional; ao fazê-lo, dinamiza determinados nichos de consumo simbólico que se constituem a partir do cruzamento das políticas culturais públicas privadas e das empresas e organizações culturais privadas, resultando na conformação e consolidação de ciclos de entretenimento e diversão, como os festejos juninos.

Por outro lado, o Programa BNB de Cultura apresenta-se como um índice de imbricação direta entre as duas categorias de direitos culturais destacadas na primeira seção deste capítulo. Como instituição estatal pública que mantém um programa regular de cultura, o Banco do Nordeste está alinhado às diretrizes das políticas culturais federais implementadas pelo Ministério da Cultura $^{31}$, assim enfatiza a primeira categoria de direito cultural ao criar condições para a promoção, atualização e consolidação das matrizes culturais sertanejo-nordestinas (ou seja, desdobrando o registro do direito à identidade). Por outro lado, desdobra também a segunda categoria, ao possibilitar mecanismos de acesso (centros culturais e exigência de projetos originários de médios e pequenos municípios) aos bens e serviços culturais que portam em suas linguagens e conteúdos as matrizes da cultura popular sertanejo-nordestina. Seguindo essa mesma senda, na entrevista concedida por Nogueira, o coordenador do Programa $B N B$ de Cultura menciona que o Banco do Nordeste está realizando um conjunto de parcerias para obter recursos de outras instituições da administração federal, como por exemplo, o BNDES. Segundo Nogueira, já há alguns convênios envolvendo o BNB e o BNDES nesse sentido, sendo que esse último tem interesse em aportar recursos para a cultura mediante o Banco do Nordeste, devido à capilaridade e legitimidade da instituição na região ${ }^{32}$, a exemplo do edital BNB de Cultura 2011.

Desde 1995 o BNDES (Banco Nacional de Desenvolvimento Econômico e Social) lança mão de recursos indiretos, não reembolsáveis, para apoiar e financiar projetos culturais, mas foi a partir de 2006, com a criação do Departamento de Economia da Cultura (DECULT), que a instituição passou a estabelecer linhas de crédito para alguns setores antes não contemplados, como, por exemplo, o audiovisual, âmbito no qual foi criado o Procult/Audiovisual, destinado a dinamizar a cadeia produtiva do audiovisual e orçado em cerca de R\$ 175 milhões. O Decult (Departamento de Economia da Cultura) está dividido em duas gerências. A Gerência de Comunicação e Cultura, que trata dos aspectos ligados ao patrocí- 
nio, através da utilização das leis de incentivo ou de recursos próprios, e a Gerência de Investimentos, que destina, na forma de empréstimos e créditos acionários, recursos para determinados segmentos, como cinema, televisão e música.

O BNDES atua a partir de quatro dispositivos operacionais de fomento: crédito de longo e médio prazo a juros baixos para grandes empresas; participação no capital de empresas, inclusive estatais; investimentos em fundos privados e publico, que envolvem, em geral, riscos; e, por fim, crédito de curto prazo para empresas de menor porte. Todos esses dispositivos, a partir de 2005, mediante o DECULT, passaram foram disponibilizados as empresas de cultura e a produção cultural em geral. A primeira operação do DECULT foi a liberação, em fevereiro de 2007, de $\mathrm{R} \$ 7$ milhões para construção de um complexo de estúdios para a produção de filmes, espaços e espetáculos de exposição em São Paulo. O DECULT apresenta um caráter bifronte, atua como patrocinador (inserindo o BNDES no elenco das empresas patrocinadoras que lançam mão das leis de incentivo fiscal) e como investidor, ou seja, como um empreendedor de determinados projetos culturais, que tem participação nos lucros e ganhos econômicos. Ao atuar de acordo com a modalidade patrocínio (uma das que compõem o mecenato) através das leis de incentivo, a gerência transfere dinheiro público (já que o BNDES é uma empresa estatal), ao contrário do que ocorre com as empresas privadas, para a produção cultural, explorando publicitariamente o prestígio dos bens culturais. Por outro lado, a segunda gerência, ao atuar diretamente como empreendedora (através da concessão de empréstimos e do investimento direto), atesta a importância que os bens e serviços simbólico-culturais têm para a dinâmica de crescimento e diferenciação da economia contemporânea de serviços.
O elo entre BNB e BNDES leva a perceber como essa interface consubstancia a dilatação do conceito de desenvolvimento trabalhado na primeira seção deste capítulo. Nos documentos de justificação das políticas implementadas por essas instituições a aproximação entre cultura e desenvolvimento é patente. Ambos deixam claro que a noção convencional de desenvolvimento (que podemos chamar de clássica, e que está ligada ao crescimento econômico e material) deve ser ampliada, ou seja, para uma noção mais dilatada e integradora, realizadora das potencialidades humanas, tal como ressalta Sahlins. No entanto, tal como foi evidenciado a partir a tessitura do repertório discursivo UNESCO, a noção clássica de desenvolvimento não desaparece. Tal noção, como atesta a criação do Departamento de Economia da Cultura e sua Gerência de Investimento, está presente no desenho geral das políticas culturais públicas, assim como sua dimensão contemporânea mais dilatada aparece no Programa BNB de Cultura, abrigando as duas categorias de direitos culturais assinaladas.

\section{CONSIDERAÇÕES FINAIS}

Como se pode notar, as três empresas aqui destacadas, Petrobrás, Banco do Nordeste e BNDES, atuam de maneira bastante específica no domínio da produção cultural. A Petrobrás, através da principal modalidade do mecenato (o patrocínio), sendo a maior captadora de recursos da Lei Rouanet, fomenta ações culturais em todo o país, granjeando títulos (como o selo de responsabilidade cultural concedido pela Secult/Ceará) e legitimando sua marca; ao mesmo tempo em que mantém uma política cultural própria, concentrada no Programa Petrobrás Cultural. O Banco do Nordeste, por sua vez, também 
mantém ações, fomentando projetos a partir da captação da Lei Rouanet, concentrados na região Nordeste, acumulando também títulos, como o selo de responsabilidade cultural concedido pela Secult/Ceará. Por outro lado, tal qual a Petrobrás, mantém uma política cultural própria, concentrada no Programa BNB de Cultura, que visa agregar valor material e simbólico à marca da empresa por meio da associação desta às expressões e manifestações da cultura popular sertanejo-nordestina. Já o BNDES, atua, além das duas dimensões exploradas pela Petrobrás e Banco do Nordeste, como financiador direto da produção cultural, atuando também como um banco de fomento cultural, que repassa recursos às organizações e empresas privadas, como canais de televisão, produtoras cinematográficas, editoras, gravadoras, entre outras.

Essas distintas formas de usos da cultura permitem as empresas acumular recursos de prestigio, cuja dinâmica faz com que a produção cultural figure como uma grande fonte de recursos simbólico-econômicos no interior nos sistemas de concorrência e gestão das marcas empresariais. Com efeito, impõe-se uma indagação (que ultrapassa os limites deste trabalho): como, por que e sob que condições a produção cultural tornou-se uma das fontes mais candentes de produção de valor simbólico e material no mundo contemporâneo? A resposta a essa indagação passa irrevogavelmente pelo advento de um novo temário de justificação envolvendo as relações entre produção cultural e as políticas culturais, cuja trama envolve aspectos como cultura e desenvolvimento, direitos culturais, cidadania cultural, diversidade e cultura popular, indústrias da criatividade e economia da cultura, entretenimento e diversão, arte e técnica, entre outras.

\section{Bibliografia:}

ALVES, E.P.M. A economia simbólica da cultura popular sertanejo-nordestina. Maceió: Edufal, 2011.

BARBOSA, Frederico. Imagens na pedra: Políticas Culturais no Brasil. Tese de doutorado defendida junto ao Programa de Pós-graduação em Sociologia da Universidade de Brasília, 2000.

BAUMAN, Zygmunt. Modernidade líquida. Rio de Janeiro: Jorge Zahar Editora, 2001.

BOTELHO, Isaura. Dimensões da cultura e políticas públicas. São Paulo: Itaú Cultural, 2004.

CESNIK, Fábio de Sá. Guia do incentivo à cultura. São Paulo: Editora Manole, 2007.

EVANGELISTA, ELY. A UNESCO e o mundo da cultura. Goiânia: UNESCO/UFG, 2003.

FONSECA, Maria Cecília Londres; CAVALCANTI, Maria Laura Viveiros e Castro. Patrimônio Imaterial no Brasil: legislação e políticas estaduais. Brasília: UNESCO, 2008.

MOREIRA, Gilberto Passos Gil. Discursos do ministro da cultura. Brasília: Ministério da Cultura, 2003.

REIS, Ana Carla Fonseca. Economia da cultura e desenvolvimento sustentável. São Paulo: Editora Manole, 2007.

RUBIM, Albino Canelas (org.). Teorias e políticas da cultura. Salvador: Edufba, 2006.

TEIXEIRA, João Gabriel L.C. (org.). Patrimônio Imaterial, performance cultural e (re) tradicionalização. Brasília: Transe/Ceam/UnB, 2004.

THROSBY, David. Economics and Culture. Cambridge: University Press, 2001.

TOLILA, Paul. Economia e cultura, lluminuras: São Paulo, 2007.

WILLIAMS, Raymond. Cultura São Paulo: Paz e terra, 2000.

WO, Chin-Tao. Privatização da cultura. São Paulo: Boitempo Editorial, 2006.

YÚDICE, George. A conveniência da cultura. Belo Horizonte: UFMG, 2005. 
${ }^{1}$ ALVES, E.P.M. A economia simbólica da cultura popular sertanejo-nordestina. Maceió, Edufal, 2011.

2 No momento em que esse trabalho é revisado, abril de 2011, encontra-se tramitando no Senado Federal a nova proposta da Lei Rouanet.

3 Chin-Tao Wo, Privatização da cultura: intervenção corporativa nas artes desde os anos $80.1^{\circ}$ edição, Boitempo, São Paulo, 2006.

${ }^{4}$ Chin-Tao Wo, Privatização da cultura: intervenção corporativa nas artes desde os anos $80.1^{\circ}$ edição, Boitempo, São Paulo, 2006.

5 Tecnologia SESI de cultura e as leis de incentivo à cultura, Vol I. www.sesi.org.br

${ }^{6}$ Cristiane Garcia Oliveira. Cultura neoliberal. $1^{\circ}$ edição, Instituto Pensarte, São Paulo, 2006.

${ }^{7}$ Revista Itaú cultural, $n^{\circ} 3$, leis de incentivo e produção cultural, 2006.

${ }^{8} \mathrm{O}$ desfio de elaborar e viabilizar projetos culturais sob as diretrizes da tecnologia SESI de cultura, www.sesi.org.br

9 www.institutopensarte.org.br

${ }^{10}$ Fonte: Ministério da Cultura (Minc).

11 O desafio de elaborar e viabilizar projetos culturais sob as diretrizes da tecnologia SESI de cultura, Brasília 2007.

12 Idem.

${ }^{13}$ Estudos das leis de incentivo à cultura, parte I. www.sesi.org.br

14 Instituto Cultural Cidade Viva, Perfil das empresas patrocinadoras, $1^{\circ}$ edição, São Paulo, 2003

15 ALVES, E.P.M. A economia simbólica da cultura popular sertanejo-nordestina. Maceió, Edufal, 2011.

${ }^{16}$ Zigmunt Bauman, Cultura: rebelde e ingovernável, in: Vida liquida. $1^{\circ}$ edição, Jorge Zahar editor, Rio de Janeiro, 2007.

17 www.petrobrascultural.org.br
18 O BNDES é um dos maiores investidores diretos na cadeia produtiva do audiovisual brasileiro, notadamente no que concerne a filmes nacionais, tendo participação direta nos ganhos e lucros desses filmes.

19 Acerca da gênese de expansão desse mercado no Brasil ver Renato Ortiz, A moderna tradição brasileira.

${ }^{20}$ Perfil das empresas patrocinadoras de cultura.

${ }^{21}$ Mercado Cultural, Leonardo Brant, Instituto Pensarte; Guia brasileiro de produção cultural 2007, Edson Natale e Cristiane Olivieri; Guia do incentivo à cultura, Fábio de Sá Cesnik.

${ }^{22}$ Entrevista realizada no dia 07 de agosto de 2008, na sede do Banco do Nordeste, em Fortaleza, CE.

${ }^{23}$ Nos dias 16 e 17 de abril de 2009 ocorreu, na sede do Centro Cultural do Banco do Nordeste, em Fortaleza, $\mathrm{CE}$, o $1^{\circ}$ Seminário BNB de Política Cultural, tendo como um dos temas do evento o Programa BNB de Cultura.

${ }^{24}$ Programa instituído pelo governo federal por meio do Decreto de 25 de agosto de 2008.

25 Ver, por exemplo, os centros culturais da Caixa Econômica Federal, do Banco do Brasil e também de instituições financeiras de controle privado, como os Bancos Bradesco, Unibanco e Itaú.

${ }^{26}$ Programa BNB de Cultura, edição 2009, Banco do Nordeste: www.bnb.gov.br

${ }^{27}$ Entrevista realizada no dia 07 de Agosto de 2008, na sede do Banco do Nordeste, em Fortaleza, CE.

${ }^{28}$ Por exemplo, o programa Fazcultura, da Secretaria da Cultura do Estado da Bahia.

${ }^{29}$ Também o programa Petrobrás cultural.

${ }^{30}$ www.ibge.gov.br

${ }^{31}$ Programa de capacitação em projetos culturais. Realização Ministério da Cultura em parceria com a CNI, SESI e BNB.

32 Entrevista realizada no dia 07 de agosto de 2008, sede do Banco do Nordeste, em Fortaleza, CE.

Contato:

Elder Patrick Maia Alves

epmaia@hotmail.com

\section{Artigo recebido em Maio de 2011}

Artigo aprovado em Maio de 2011 